Вука Јеремић

Наташа Васиљевић

Универзитетска библиотека

„Светозар Марковић“
025.2:027.7(497.11)

https://doi.org/10.18485/melissa.2017.16.1.ch12

\title{
НАБАВКА ПУБЛИКАЦИЈА У УНИВЕРЗИТЕТСКОЈ БИБЛИОТЕЦИ У УСЛОВИМА ПЕРМАНЕНТНЕ КРИЗЕ
}

\section{Сажетак}

У већини дефиниција појма криза подразумева се својство ограниченог трајања тј. привремености, после чега следи или побољшање које се креће ка опоравку или погоршање које води у пропаст. Кад је реч о кризи српске културе, она је изашла из оквира ове дефиниције и постала редовно, трајно стање. О томе најбоље сведочи (не)функционисање културних и образовних институција у периоду који траје готово три деценије. Током тог предугог времена никада се нису стекли услови да буде проглашен престанак кризе, па су посленици у наведеним институцијама били принуђени да у неизвесној борби за опстанак прилагоде своје делатности специфичном амбијенту перманентне кризе којој се не назире крај. О томе на парадигматичан начин сведочи функционисање набавке књига као основне делатности Универзитетске библиотеке „Светозар Марковић“, која је у дуготрајним ванредним околностима не само опстала и сачувала континуитет, већ се настојало и на унапређењу неких њених аспеката, упркос чињеници да деценијама уназад ресорно министарство не одваја никаква наменска средства sа куповину публикација неопходних за одвијање наставно-научног процеса на универзитету.

Кључне речи: Универзитетска библиотека, набавка публикација, криза

$$
\begin{array}{r}
\text { Када дувају ветрови промена } \\
\text { неки људи граде склоништа, } \\
\text { а други праве ветрењаче. }
\end{array}
$$
(кинеска пословица)

Појам кризе у класичном значењу односи се на пролазно тешко стање, дисконтуитет настао прелазом са једног на други поредак економских, друштвених, културних структура, али је услед особено- 
сти савремене цивилизације чија су основна одлика брзе промене које диктира технолошки развој, криза постала начином битисања коме се и најстабилнији стубови друштва морају прилагодити ради сопственог опстанка ${ }^{1}$. Делатност набавке публикација у библиотекама уско је везана за оно што криза подразумева због своје зависности од финансирања, али се често заборавља чињеница да је њена мисија стварање баштине за будуће генерације, обезбеђујући притом услове и за вертикално и за хоризонтално транскултурно окружење. У том смислу рад је усмерен на две подтеме: Континуитет језика и културе у условима друштвене кризе - у смислу активног става у условима хронично негативног амбијента са мотивом очувања континуиране културно-образовне делатности упркос перманентној кризи и: Културна баштина и библиотеке - у смислу ултимативног развоја библиотечког фонда као предуслова креирања и очувања универзитетске баштине која обезбеђује транскултурну перспективу на академском нивоу.

Криза српске културе има све одлике глобалне кризе културе, али и специфичности за које је заслужна културна политика која је у току претходних тридесетак година успела да доведе у питање одрживост практично свих традиционалних културних институција. Овај дуги период борбе са кризом, заправо транзицијом из једне кризе у другу, обележен је различитим начинима прилагођавања као једине могућности функционисања у датим условима. Проактивност институција постала је услов њиховог опстанка у финансијски нестабилном окружењу које карактеришу брзе промене технологије, власти, друштвене структуре, културних навика.

Из сасвим другог угла, активна улога библиотека као институције огледа се у чињеници да оне учествују у решавању различитих врста кризе на специфичан начин, како на индивидуалном, тако и на друштвеном и глобалном плану. На индивидуалном плану најважнији задатак библиотека очитује се у обезбеђењу извора знања и услова за несметан рад. Посебно су значајне када дође застоја у учењу и научном истраживању јер се у овим установама може премости-

1 Јовановић, Бојан. Од кризе културе до културе кризе, стр. 53-62 у: Култура и криза : излагања на 25. заседању Крушевачке филозофско-књижевне школе [2015] / [уредници Марко Недић, Милош Петровић]. - Крушевац : Културни центар Крушевац : Град Крушевац : Крушевачка филозофско-књижевна школа, 2016. - 190 стр. 
ти не само налажењем одговарајућих извора информација већ и консултацијама у мање формалној атмосфери. Осим тога, библиотеке, идеално замишљене као острва тишине, мира и контемплације, могу помоћи у решавању психолошких проблема². На друштвеном плану, библиотеке често остају места где се грађани могу обскрбити важним обавештењима у кризним ситуацијама које проузрокују блокаду медија (политика, ратови, непогоде), док паралелно врше функцију места социјализације људи свих старосних узраста и професионалних статуса, а нарочито млађе популације којој остаје све мање локација за спонтано дружење изван виртуелног света. Коначно, на глобалном плану, где све више царују униформност, медијска контрола и манипулација, потрошачки менталитет и тривијализација свих садржаја, библиотеке - и саме захваћене овим трендовима, ипак за сада остају макар уздрмане тврђаве истраживачке мисли и слободног духа, а у односу на многа друга места, ексклузивне дестинације где корисници нису само купци и потрошачи већ коликотолико слободномислећи грађани.

Када се говори о кризи набавне делатности Универзитетске библиотеке, не мисли се само на одсуство финансирања основне институционалне делатности (ова установа, наиме, више од четврт века функционише практично без буџета за куповину публикација), већ је реч и о статусу специјализоване професије у оквиру струке. Специфични послови који се одвијају у њеним оквирима недовољно су видљиви и по правилу недовољно атрактивни за спонзорство па и државно буџетирање, будући да подразумевају тихо и систематично улагање из кога је тешко извући брзе и корисне политичке поене. У прилог овој тврдњи говоре многобројни примери који еклатантно показују да је финансирање сваке друге активности (опрема, дигитализација, манифестације, сајмови...) приоритет комисија које опредељују средства пројектног финансирања. На вапијући недостатак финансија надовезало се и кадровско осипање због административне забране запошљавања, као и просторна скученост и техничка (не)

2 Поготово када се има у виду и развој такозване библиотерапије која се успешно примењује као терапеутски метод за лакше дијагнозе али и као допунска активност у лечењу тежих психичких обољења. Видети у: Ouaknin, Marc-Alain. Bibliothérapie : lire, c'est guérir. - Paris : Seuil, 1994. - 439 str. 
опремљеност што све заједно отежава функционалан рад. Повремено су искрсавале и специфичне тешкоће који су екцесне и временски ограничене али наносе велику штету и фонду и континуитету сарадње као што је бизарни случај наметања културног ембарга Србији 1992. године или још бизарнија криза управљања установом када током безмало целе деценије оснивач није именовао одговорно лице.

На све наведене аспекте дуготрајне кризе са којом Универзитетска библиотека настоји да изађе на крај, на ову установу, сасвим у складу са важећом културном парадигмом, такође делује притисак ширег окружења и глобалних трендова. Набавна делатност библиотека на глобалном плану суочена је са гашењем размене као начина набавке у све већем броју партнерских институција услед њене финансијске неисплативости а такође и миграцијом ка дигиталним облицима грађе која захтевају већу техничку опремљеност него што библиотека поседује. Већ прилично уздрман концепт демократизације знања и универзалне приступачности информација, почетком претходне деценије захтевао је од библиотека да све изворе учине доступним, само да би се суочиле са ограничењима строгих система лиценци и одредби о ауторском праву. Истовремено су расла очекивања да се сопствена баштина што потпуније интегрише и учини приступачном на глобалном нивоу преко великодушно финансираних заједничких платформи и пројеката дигитализације реализованих током претходне две деценије. Ово је подразумевало фокусирање енергије и финансија на већ постојећу баштину, при чему се губи из вида да ће оно што се ствара и сакупља данас, бити баштина будућих покољења. Коначно, велики притисак на библиотеке долази са развојем информационих технологија, где се очекује апсолутно парирање светским стандардима упркос очигледно недовољној опремљености и мањку компетенција на свим нивоима. Да би макар у некој мери одговориле на наведена очекивања, библиотеке се окрећу оним пројектима који обезбеђују финансијске, техничке и кадровске услове за реализацију наведених актуелних (прецизније речено, трендовских) активности, при чему традиционалне делатности попут набавке остају по страни. Како време пролази и ванредно стање постаје редовно, не помињу се више ни долазећа «боља времена» у којима ће се променити ова погубна политика, а у свести библиотекара ствара се искривљена пред- 
става у којој је носећа делатност библиотеке на коју се надовезују све остале, са добрим разлогом пребачена на споредни колосек.

У већ поменутом дуготрајном периоду непостојања наменског буџетског финансирања набавне делатности, пажња се најпре усмерила на покушаје да се фонд комплетира аплицирањем на конкурсе за пројекте и на предлог новог законског решења обавезног академског примерка. Међутим, основна делатност библиотеке према интерним правилницима надлежних министарстава није могла бити финансирана ни пројектно ни програмски, будући да је у питању редовна активност установе за коју се претпоставља редовно издвајање средстава (последњи пут је била ставка редовног буџета само у једном једином наврату сада већ давне 2005. године). Са друге стране, иницијатива укључивања Универзитетске библиотеке «Светозар Марковић» у Закон о обавезном примерку, по моделу који је у примени у Уједињеном краљевству, резултирала је њеним увођењем у преднацрт закона у марту 2010, да би наредне године из усвојеног текста била потпуно изостављена. Било је потребно скоро седам година лобирања да би она коначно била наведена као корисник институције обавезног примерка.

Набавна служба не може се посматрати ван димензије установе у којој функционише, али се ни библиотека не може посматрати мимо окружења у коме своју делатност обавља. У бити су обе ограничене својом академском, друштвеном и економском димензијом. Првобитна намена, она која је инхерентна библиотеци, у суштини јесте подршка процесу учења и истраживања на универзитету (али и у широј заједници), при чему се њен «производ» врло условно и за потребе доказивања њене исплативости, може назвати додатом вредношћу у смислу знања као економске категорије. Али библиотека јесте и стваран простор у времену када је битисање индивидуа - укључујући и оне које припадају академској заједници - све више виртуелно, када је и њихово образовање све више такво. У овом се простору размењује жива реч ван ограничења које намеће припадност матичној образовној институцији, у коме се корисници могу информисати о сасвим другим темама од оних које се проучавају. Овај стваран простор, са свим својим недостацима, има важну друштвену функцију за кориснике који (још увек) желе да се упознају, дру- 
же, размењују искуства у непосредној комуникацији. Иако, према традиционалној организациоји послова, набавна служба не припада простору намењеном корисницима, она је ипак, током година, својим ангажманом у сфери промотивних активности успела да спонтано стекне статус «отворених врата» за интеракцију са корисницима. Ова врста контаката није била од значаја само за њих, већ је погодовала и жељи да се, и поред тешких околности, на сваки расположив начин унапреди рад у оквиру набавне делатности.

Кад је реч о унапређењу службе, ваља напоменути да се Одељење набавке није систематски бавило применом традиционалних менаџерских алата и техника, јер би то додатно компликовало унутрашњу организацију, већ се усмерила ка што већем ангажовању запослених, дакле већој продуктивности са тенденцијом да се један део времена одвоји и за нестандардне и креативне послове као што су организовање изложби, промоција и предавања, стручна усавршавања формалног и неформалног типа и учешће на стручним и научним скуповима, са идејом да свака од наведених активности на специфичан начин може допринети унапређењу како струке, тако и службе.

Ипак су неки механизми који се могу сврстати у област менаџмента поштовани и на нивоу одељења и на нивоу библиотеке, а то су превасходно принципи максималног искоришћавања постојећих ресурса кроз процесе концентрације, акумулације, комплементације, очувања и обнављања постојећих ресурса. Концентрација као коришћење људских потенцијала у правцу јединственог циља за који је потребан консензус, постигнута је организацијом у којој се по општем савладавању вештина потребних за рутинско обављање свих послова заступљених у одељењу, задаци расподељују према тренутној расположивости запослених, увек имајући у виду и већ поменуте планиране нестандардне активности. Акумулација подразумева очување и континуитет, како у кадровском смислу, тако и кроз настојање да се очува стара и ретка грађа и ексклузивне колекције. У процесу акумулације посебно је важна била могућност дигитализације реткости и похрањивања изворно дигиталних материјала у репозиторијуме доступне јавности што на ширем плану чини библиотеку јединственим виртуелним ентитетом. О комплементацији као сарадњи са другим институцијама, није згорег напоменути да се повезивањем постојећих ресурса, било да је 
реч о традиционалном или дигиталном фонду, информационим пунктовима или ресорним стручњацима, добија додата вредност која је у кризним временима (и не само у њима) кључ одрживости. Очување и обнављање укључују поред већ наведеног дигитализовања постојећих фондова, планирање нових платформи и носилаца информација. У том се смислу већ може говорити о обликовању и презентацији будуће универзитетске баштине Универзитета у Београду, јединствене колекције свих садржаја који сведоче о његовом развоју, али и о развоју науке у Србији, као универзитетске паралеле завичајних колекција.

Напоменимо ипак да је за будуће пројекте набавне делатности и саму будућност Универзитетске библиотеке, највећи фактор ризика проблем кадрова, будући да је услед забране запошљавања која је на снази већ пет година, особље библиотеке смањено за петину. Истовремено, читава једна генерација младих људи, иако обучена за врло специфичне послове током волонтирања у Библиотеци, није могла да буде интегрисана у колектив нити да донесе ону врсту промене својствене младим генерацијама.

Не као менаџерска одлука, већ као спонтани одговор на кризу, по принципу "да се спасе што се спасити може», у хроничном недостатку једног вида набавке (куповина) унапређен је други вид (поклон), захваљујући чему је сачуван континуитет функционисања набавне делатности. Тако је у условима непостојања буџета кључни фактор повећања ресурса постало снижавање критеријума за пријем безусловних поклона, из којих су вишкови даље уступани другим библиотекама. ${ }^{3}$ Захваљујући повећању прилива ове врсте поклона интензивирана је сарадња са другим институцијама кроз размену и циљану донацију библиотечког материјала. Паралелно је постепено уведена пракса систематске провере књига из старог фонда за сваки наслов који је добијен на поклон и замене оштећених и дотрајалих примерака, као и укључивања у фонд додатних примерака најтраженијих наслова. Ова врста ревитализације постојећег фонда у условима нор-

3 Специфичност ове врсте уступања јесте да се књиге уступају искључиво према захтевима, а не као пакети нежељених публикација. Другим библиотекама је током 2017, на пример, понуђено у три наизменична круга укупно 11.164 наслова дупликата из добијених поклона. Књиге су се, као и претходних година, нудиле најпре у оквиру међународне размене, затим високошколским, па јавнимбиблиотекама у Србији. 
малног функционисања набавне делатности вероватно и не би била изводљива на начин на који је током година постепено увођена. Све наведено је добра илустрација за тврдњу да управо промене и кризне ситуације и начини на које се спрам њих поставља организација воде ка формализацији и имлементирању механизама помоћу којих организација функционише.

Комуникација са колегама, представницима медија, власти, издавачима, спонзорима и стварање окружења сарадње и синергије, кључни је фактор учвршћивања позиције наше институције. У временим кризе посебно су биле драгоцене оне врсте сарадње у којима је једна од страна била донатор или партнер у размени неусловљеној постојањем еквивалента, будући да су се на тај начин градили пријатељски односи који су на дуже стазе и самом донатору/значајнијем партнеру доносили корист. Наведимо само пример Народне библиотеке Србије и Библиотеке Матице српске које су током дугог низа година Универзитетској библиотеци уступале велики део сопствених вишкова нових научних публикација, којима смо се бар делимично одужили када смо прегледајући велики број приспелих књига из поклона, повремено успевали да нађемо и уступимо им минусе националног фонда.

Коначно, организовањем тематских изложби у сарадњи са другим институцијама, поједини делови фонда су рекаталогизовани тј. по први пут су постали доступни у електронском каталогу, други су дигитализовани, а сви заједно су преко изложби и каталога представљени не само академској већ и шриој јавности. Свака од изложби и активности у мањој или већој мери пропраћена је и у медијима, што је за допринело не само популаризацији фонда Универзитетске библиотеке, већ и саме институције као живог чворишта које делује у оквиру Универзитета у Београду. ${ }^{4}$.

Залагањем нове управе, Универзитетска библиотека успела је да се упише у списак оних које примају публикације из откупа Министарства културе Републике Србије. После добијања огледних

4 Стефановић, Иван. Стратегије организација у дисконтинуираном окружењу. - Београд : Задужбина Андрејевић, 2010. - 92 стр.

На пример http://www.politika.rs/sr/clanak/381003/Frojd-i-li-Jung-u-Doktorovoj-kuli, http://www.rts.rs/page/stories/sr/story/16/kultura/2292350/izlozba-sekspir-i-servantes--400-godina-od-smrti.html, http://studiob.rs/izlozba-kontroverza-hajdeger-u-univerzitetskoj-biblioteci/ 
примерака из откупа 2014, већ наредне године је уврштена на списак библиотека које примају публикације из откупа и то у највишој, шестој,категорији. Бенефит добијања публикација из откупа солидарно је поделила са универзитетским библиотекама из Ниша и Крагујевца које су у једнако незавидној ситуацији када је у питању финансирање набавне делатности. ${ }^{5}$

Осим откупа, у Универзитетској библиотеци консолидује се већ поменути вид набавке, обавезни академски примерак ${ }^{6}$. Будући да се (осим кад је реч о акредитованим високошколским и научним институцијама) не шаље по аутоматизму и не односи на целокупну издавачку продукцију, већ само оне публикације које имају академски значај, овај вид набавке подразумева систематично праћење издаваштва, селекцију по прецизно одређеним критеријумима, поручивање и издавање потврда пријема, упућивање рекламација и грађење посебног односа са издавачима како из академског, тако и из комерцијалног сектора. Обавезни академски примерак који се прима од марта 2016. године усмерио је Универзитетску библиотеку на сарадњу са три различите врсте издавача. Од првих, високошколских институција и научних института очекујемо (и најчешће и добијамо) сва нова штампана издања. Јачање академских веза требало би у наредном периоду да произведе и редован прилив нестандардних наставних материјала који не подлежу овом закону и израду њихових онлајн доступних колекција. Комерцијални издавачи су хетерогена групација која принципе набавке универзитетске библиотеке често произвољно тумаче, и ту је покривеност захтева убедљиво најмања. Проширење сарадње са овом групацијом за сада се своди на спорадичне појединачне захтеве за услугама од стране издавача, као што су промоције нових издања или пак позајмица грађе из фонда неопходне за различите издавачке пројекте. Нова мрежа обострано корисне сарадње успостављена је пре свега са некомерцијалним из-

5 Тако је, на пример, у оквиру откупа 2017. године примљено је 1.308 наслова у вредности од 1.165.358 динара, од којих је, према договору, Универзитетским библиотекама у Нишу и Крагујевцу уступљено 645 наслова укупне вредности 498.218 динара.

6 Обавезни академски примерак публикација у укупној набавци у 2017 учествује са $28,26 \%$, а уколико се као обавезни примерак третира и прилив академских радова који се традиционално инвентарише као поклон, постаје доминантан део новог фонда са $39,81 \%$ наслова 
давачима тзв. сиве литературе коју карактерише добар одзив, проистекао из потребе ових издавача за промоцијом и пласманом.

Откуп и обавезни примерак као важни чиниоци у процесу стварања будуће баштине функционишу, с тим што се надамо већој ажурности академске заједнице и већем одзиву комерцијалних издавача. Ако би се у догледно време, после скоро три деценије, обезбедио и буџет за куповину публикација, коначно би се функционисање набавне делатности Универзитетске библиотеке као српске централне научне библиотеке, приближило академским стандардима развијеног света. Досадашња пракса изазивања личних и институционалних поклона за попуну основног и резервног фонда подразумева трошење доста времена и енергије са неизвесним резултатом.

Може се рећи да је улога универзитетске библиотеке двојака и да се остварује и на културном и на научном плану. На једној страни, доприноси ширењу видика појединца друштвеном интеракцијом, развојем критичког мишљења, усвајањем етичког кодекса и слично, а на другој, обезбеђује конкретан приступ конкретним изворима информација неопходним за учење и научно истраживање. Симболички, може се у тој двострукој улози библиотеке, па сходно томе и послу набавке, наћи доста тога прозаичног, али и поетичног. А ако се настави у истом тону, може се такође рећи да се управо због кризе све одвија најчешће у драмској форми јер подразумева тражење (углавном незаинтересованих) спонзора, управљање (најчешће неизазваним и понекад нежељеним) поклонима, и као најважније - тежњу да се набавна делатност не претвори у театар апсурда.

\section{Литература}

Извештаји Одељења набавке Универзитетске библиотеке „Светозар Марковић“ 2008-2017

Јовановић, Бојан. Од кризе културе до културе кризе, стр. 53-62 у: Култура и криза : излагања на 25. заседању Крушевачке филозофско-књижевне школе [2015] / [уредници Марко Недић, Милош Петровић]. - Крушевац : Културни центар Крушевац : Град Крушевац : Крушевачка филозофско-књижевна школа, 2016. - 190 стр. 


\footnotetext{
Криза и перспектива знања и науке : [наука и савремени универзитет] : тематски зборник радова / [главни и одговорни уредник Бојана Димитријевић]. - Ниш : Филозофски факултет, 2012 . - 566 стр.

Стефановић, Иван. Стратегије организација у дисконтинуираном окружењу . -Београд : Задужбина Андрејевић, 2010. - 92 стр.
}

\title{
Vuka Jeremić \\ Nataša Vasiljević
}

\section{BOOK ACQUISITION IN UNIVERSITY LIBRARY IN CONDITIONS OF PERMANENT CRISIS}

\begin{abstract}
Summary
Most definitions of the term crisis contain the characteristic of a limited duration, followed by an improvement that moves towards recovery or deterioration leading to ruin. When we talk about the crisis of Serbian culture, it came out of the scope of this definition and became a regular, lasting state. This is best evidenced by the (non)functioning of cultural and educational institutions in a period that lasts for almost three decades. During that long period of time, the conditions for the end of the crisis have never been met, so the employees in these institutions (in an uncertain struggle for survival) were forced to adjust their activities to the specific atmosphere of a permanent, endless crisis. This is paradigmatically evidenced by the functioning of the books acquisition as the main task of the University Library "Svetozar Markovic". In long-term extraordinary circumstances this key library activity not only survived and preserved continuity, but also tried to improve some of its aspects, despite the fact that for decades, the ministry of science and education has not allocated any funds for the purchase of publications which are necessary for the teaching-scientific process at the university.
\end{abstract}

Key words: University library, books acquisition, crisis 